\title{
READERS
nsight
}

Journal of Economic Info (JEI)

ISSN:2313-335X

www.readersinsight.net/jei

\section{Performance and evaluation of portfolio of mutual funds}

\author{
Umair zuhair ${ }^{1}$, Agha Amad Nabi²* \\ ${ }^{1,2}$ Department of Business Administration Iqra University \\ * Corresponding author: ammadagha786@gmail.com
}

\begin{abstract}
The basic approach of any kind of investor is to handle and minimize the risk and increase their profits. It is common fact that to manage the risk is not to have all eggs in a basket in monetary markets and this saying is familiar as diversification. The diversifications need decision regarding which basket to have which eggs and how much eggs should have in the basket. The lack of financial expertise in the context of mutual funds for making investment in markets has introduced mutual funds with the state of mind of financial experts. The experts of financial markets have only advantage since the fact that it is always win-win situation for them who don't know about investment and decreasing the risk via managing funds in effective way by bigger portfolios and sufficient amount of money. As the mutual fund industry of Pakistan expanded with some pace in first decade of this century and due to this reason the performance evaluation of this industry become critical and hot topic.

The study aims to measure the performance of Pakistani mutual fund industry from 2014 to 2017. There are total 233 mutual funds operating in the mutual industry of Pakistan, out of 233 mutual funds, total 45 mutual funds were selected for the study; 23 mutual funds were from equity while only 22 mutual funds were selected form money market. Sharpe ratio was used to measure the riskadjusted performance of mutual funds and the Sharpe ratio in both equity funds and money market funds are positive, thus indicating that funds managers have the ability to diversify investment to decrease the risk.
\end{abstract}

ARTICLE INFORMATION

\section{Received: 27 February 2015 \\ Revised: $\quad 10$ April 2015 \\ Accepted: 25 April 2015}

DOI 10.31580/jei.2i2.85

\section{Introduction}

Expanding number of shared finances in the created budgetary markets demonstrate financial specialist inclination for this mode of venture. We watched that common trust industry has encountered enormous development, at the same time it is still a late marvel in a percentage of the making countries. As a consequence of its snappy advancement mutual funds are creating energetically mutual funds are of two sorts open completed and shut finished, shut finished are those whose shares are at first offer to open and after that exchanged the secondary showcase between different financial specialists whereas open finished stores are those whose membership and readapt of shares are permitted on constantly bases. Mutual funds are establishments built with the end goal of profiting those financial specialists who can't stand to put straightforwardly in different kind of securities. Mutual funds were displayed in Pakistan in 192, with the comprehensive group offering of NIT [national Investment Trust]. Starting now, this is the fundamental open completed mutual fund working openly segment. The advancement of ICP [investment Corporation of Pakistan] in 1966 offered a course of action of closecompleted mutual funds. Pakistani mutual funds have experienced a stunning change amidst the period under study -1999-2005] with net resources respect created from Rs 16 billion to Rs 137 billion till June 30, 2005.however, taking a gander at Pakistani shared stores industry for the most part it is of a bit size. Pakistan holds simply Rs 1.33\% mutual funds advantages for essential securities, Mutual funds industry in Pakistan has basic room to create. Paid -up capital may look critical however the size is still unnecessarily little as appeared differently in relation to worldwide standard. Soongswang and Sanohdontree (2011) examine profitability of one hundred thirty-eight unrestricted equity mutual funds handled by the 70 asset management firms in Thailand from 2002 to 2007. A number of diverse investment prospects of fund profitability were examined with the use of different assessment techniques. The findings recommend that profitability of the funds calculated by the 1st three techniques that are base on risk and profit considerably do perform better than the market for each investment period. The abnormal profits of the funds for shareholders are positive and determined. In the meantime, those assessed by the previous technique, which is a different-criterion strategy, result in different results: perform better and not performing, relied on investment period. Though, on standard, the funds' profitability is considerably optimistic for 3-month period of investment, as a minimum.

Nazir and Nawaz (2010) discussed that mutual fund business plays important part in most advantageous distribution as well as channelization of accessible redundant capital in the financial system. This part turns out to be a lot stronger in the upward nations like Pakistan wherever the potential investors don't have investment information, data, and services to invest in the money markets and they don't have risk ability for straight investments in chancy stock. The present study is leading the way in its environment to examine the role of diverse variables in explaining the mutual funds 
development in Pakistan. The data from 2005 to 2009 have been deployed for thirteen family equity mutual funds as well as fixed effect as well as random effect frameworks have been implied for opinion of characteristics of mutual funds development in Pakistan. The findings have indicated that assets turnover, relatives' percentage, as well as cost ratio are absolutely leading the development of mutual funds, in comparison with organization fee as well as risk adjusted profits that are pessimistically connected with mutual funds development.

Mutual funds provides the chances to low level investors who have little bit savings but don't have enough extra time to multiple profit sources to observe or focus on the dynamics of financial markets. Portfolio has the chances of decreasing the risks via diversification and effectual and competent diversification needs large funds for investing. There is gap among undersized fund holders and experts who have expertise regarding the finance thus it have filled the introduction of mutual funds.

The study aims to measure the performance of Pakistani mutual fund industry from 2014 to 2017. As the mutual fund industry of Pakistan expanded with some pace in first decade of this century and due to this reason the performance evaluation of this industry become critical and hot topic.

The research will help the investment companies in Pakistan to achieve the trust of the investors to invest funds in their portfolios. Furthermore, it will also help to induce the behavioral change of investors and to educate them to invest in Mutual Funds. The research will benefit academic area that is it will contribute to the existing body of knowledge and will provide basis for future research. The researchers can increase the independent variables and sample size or they might be more focused on open or closed ended to provide more knowledge to the market.

\section{Literature review}

William Forsyth Sharpe developed this model in 1966; it is also called reward to variability ratio. It is used to measure the excess return per unit of risk in an investment asset. The ratio of returns above the risk free returns to standard deviation is calculated; the higher the result of this ratio for the portfolio, the more the fund is suitable for investment and vice versa.

Khoranaa, Servaesb, and Tufanod (2005) studied the mutual fund sector in fifty six nations and investigate where this financial modernism has increased. The fund sector is better in nations with stronger policy, laws, as well as policy and especially wherever mutual fund investors' rights are superior protected. The sector is furthermore bigger in nations with wealthier and additional educated public, wherever the sector is grown-up, trading expenses are less and in which specific contribution pension plans are further widespread. The sector is less important in nations where problems to entry are superior. These findings show that laws as well as system, supply-side plus demand-side factors concurrently have the impact on the size of the fund sector.

Belgacem and Hellara (2011) examine the capability of famous fund distinctiveness for example the modern history performance, size of fund, organization price, age of funds, net asset worth as well as development of fund so as to clarify equity mutual fund productivity. The model was divided accordance to savings goals, plus the highly developed panel data strategy was deployed for the time from 1999 to 2006. It was found that precedent performance as well as the size of fund has an optimistic as well as major effect on potential performance for every types of fund, regardless of what performance evaluate was deployed. This can identify the continuation of economy of scale in equity mutual fund sector. It was found that additional fund distinctiveness play and vital part in describing the productivity, however their effect differ between the fund types. Altogether, findings sustain the energetic relations among fund distinctiveness as well as potential performance. The results don't take into consideration the performance of fund executive plus their capability to expand the savings chances. It appears that there are further multifaceted variables associated to the tactical activities of the director as well as pouring dissimilarity in performance in funds as compares to preceding researches have showed. It was confirmed that the proof that past performance include a number of data regarding upcoming performance with such data can be significant toward mutual fund saver. The results indicate that size of fund is significantly connected to potential performance of little fund type plus of big fund type. This can show the subsistence of economy of scale in equity mutual fund division. Additionally, the impact of the further control factors differ between the fund types, however frequently is the equivalent as in previous researches.

Lee, Yun, and Haley (2013) examine the impacts of budgetary administrations promoting divulgences via matching a substance examination filing how required cash related exposures are shown to advancement, brand and investigation takes a gander at the effects of budgetary organizations progressing exposures through matching an attachments with a between-subjects trial assessing whether the fuse of the disclosures sways buyer the disclosures likewise higher danger discernment when buyers are introduced to the cash related disclosures in shared trusts degrees of advance Likewise, the results display an interceding piece of positive responses on aura around the common trusts association exactly when clients are exhibited to advancing disclosures.

Badrinath and Gubellini (2012) give hypothetical and careful verification that, altogether, trusts neglect to meet desires amid financial extensions and outflank amid tightening impacts. It was found that this result is definitely not hearty to the more proper restrictive CAPM and to Option routines for assessing business states. The impact driving this paper is along these lines to altogether break down mutual funds execution over business cycle by disaggregating trusts into distinctive speculation destinations to focus which subsidizes have this cyclical execution and which don't. In this study, the makers use a prohibitive asset assessing display that better catches the varieties in the evaluating portion in distinctive financial states. The inventors found that retreat assurance is just advertised by specific sorts of value basic trusts. Head of quality stores don't. In an examination of dynamic mutual funds with unapproachable accomplices, it is watched that both the stocks held by the little top chiefs and in addition their stewardship of the portfolio help that execution. Drawing from the late resource assessing composed work, the creators are the first to acclimate a combined restrictive CAPM system to inspect the state-subordinate execution of mutual funds. The creators give an investigation for subsets of mutual funds divided by meander styles. Both head of and analysts in these trusts will advantage from an understanding of how portfolio execution is impacted by changing cash related conditions.

Banko, Beyer, and Dowen (2010) helps the composition on shared trusts directors, furthermore the written work on the structure of common subsidizes by demonstrating that market fixation at the advantage chief level differs significantly crosswise over styles, especially for the altered wage reserves. The paper shows that extended business center is joined with more unmistakable costs for the stores under both worth stores and for changed compensation holds. The study additionally demonstrates that expanded expenses are in part balanced by economies of extension. To begin with, it confirms the vicinity of economies of scale at the store level inside strategies. Second, it archives the region of changing of business sector focus inside distinctive. Finally, the results showed that the greatest trusts inside a family are connected with the most foremost cost extents in the posse.

Reza and Glabadanidis (2013) assessed the danger balanced execution of the administration styles of Malaysian mutual funds utilizing nine changed execution assessment measures produced by the most extreme drawdown danger measure (M-DRM) focused around the cutting edge portfolio hypothesis. A way which is feasible by the normal speculators and portfolio .It proposes another single-element model to test the most extreme drawdown beta and alpha in the MDB, 
the most extreme. Drawdown beta and the greatest drawdown CAPM can be supplanted by the traditional structures as to, beta, and the CAPM besides MSB, downside beta, and D-CAPM for modifying nine execution evaluation measures from the organization styles of Malaysian. The examination confirmation reported in this paper can be connected as info in the procedure of choice making by little and normal financial specialists and portfolio chiefs who are looking for the likelihood of partaking in the worldwide securities exchange through mutual funds. This paper was the first study to gauge another relapse display in the M-DRM system to assess the execution of Malaysian mutual funds. Furthermore, it proposes nine changed execution assessment measures in the M-DRM system shockingly.

Beaumont, Daele, Frijns, Lehnert, and Muller (2008) examine the effect of individual speculator conclusion on the return process and restrictive unpredictability of three principles US showcase records. Singular financial specialist supposition is measured by total cash streams good and done with locally arranged US mutual funds. A summed up autoregressive contingent heteroscedasticity (GARCH)in-mean purpose of investment is utilized, where our measure for individual thought enters the mean what's more restrictive unpredictability a fundamental and deviated effect on unusualness, growing it additional at the point when assessment is bearish Utilizing wording. we locate confirmation for the hold more impact, which expresses that when commotion dealers embrace a greater amount of advantage, they furthermore see their returns advancement, and the 'make space influence, which that turmoil traders are made up for the additional peril they make themselves. As opposed to existing studies utilizing unequivocal measures of business sector assessment on low testing frequencies, the utilization of day by day common stream information offers a one of a kind picture on speculators portfolio rebalancing. The results propose a formed structure that commonly tests for the impacts of normal trust streams on stock return and prohibitive flimsiness.

Noulas, Papanastasiou, and Lazaridis (2005) evaluate the profitability of equity funds in Greek from 1997 to 2000 . The assessment is base on the investigation of risk as well as profit. The risk was calculated via coefficient of variant as well as the logical risk. The findings show that there was optimistic association among risk as well as profit for the complete time, at the same time as the betas for each fund are lesser as compares to others.

Jamaludin, Smith, and Gerrans (2012) explained that in its "member's savings plan" tactical proposal, the Malaysian workers fund allow its members to spend fraction of their retirement investment in standard exterior funds. Provided there are a rising amount of entity trust funds accessible in the market, it isn't a simple job for members to build this investment assessment. The purpose of the study was to determine the professed significance of fund selection criterion inside the circumstance of retirement investment in Malaysia. In addition, it as well searches for to scrutinize the association among religious association as well as fund category. A survey based on the questionnaire was conducted between four hundred forty members. The study findings show that the position of mutual fund choice criterion varies among Muslim as well as non-Muslim associates. Precedent performance was the vital criteria appreciated by subsequently on-Muslim EPF associates. In procession with compliant to religious faith, the fund's promise toward Islamic values was the vital criteria measured by Muslim associates. Both kinds of religious associates as well measured the general status of the fund as significant criteria while choosing mutual fund.

Kaleem and Ahmed (2015) explained that the Quran exclude interest as well as promote business plus donations as interchanges. The study tries to find direction from the Holy Quran and generates a hypothetical framework of donations-base Islamic micro finance organizations that may be deployed as a substitute strategy to decrease scarcity. The study argued that donations-base Islamic organizations can be monetarily and publicly profitable because these are based on the ideas of brother hood, limited charity, plus volunteer facilities. The company may give wealth for utilization plus manufacture reasons as well as, therefore, can generally aim the financial and societal requirements of the poor peoples. Companies may assist to reduce gratitude and decrease imbalanced allocation of capital in the world.

Soongswang and Sanohdontree (2011) focused on indefinite equity mutual funds, the profitability of funds was investigated whether the profits considerably plus determinedly do better than the market; the employ of diverse measures guide funds with comparable levels. The examination deployed various metrics: the conventional fund profitability assessment measures as well as DEA method; Pearson's correlation coefficient, plus cover 6 diverse savings prospects. The findings suggest that unrestricted equity mutual funds examined in the study considerably do better than the market, as well as the funds' optimistic performance maintain for three-month period of savings, as a minimum. The best 5 funds handled by the asset management firms do better than the below 5 funds among 0.1912 as well as 1.3187 for 6 period of investment. In conclusion, that for common investors, the findings of the study may be strategy for choosing mutual funds for savings.

Baghdadabad and Glabadanidis (2013) aims to evaluate the riskadjusted profitability of the organization kinds of mutual funds with the use of 9 customized performance assessment procedures created by the greatest drawdown risk measure on the basis of the current portfolio assumption. The point is to details the results in a way that is attainable by the normal investor as well as portfolio executives. The study assesses the profitability of over four hundred mutual funds with the use of risk-adjusted profits from 2000 to 2011. It recommends a new particular-variable framework to check the utmost draw down beta as well as alpha in the model. The proof obviously shows that the substitute model of MDB, the highest draw down beta, as well as the highest draw down CAPM may be substituted by the conservative models of MVB, beta, along with the CAPM plus MSB, down side beta, plus D-CAPM for adjusting 9 profitability assessment movements from the organization kinds of mutual funds in Malaysia. Baghdadabad, Matnor, and Ibrahim (2012) aims to review the riskattuned profitability of mutual funds in Malaysia by deploying ODRMs on the basis of modern portfolio assumption, plus to signify the findings in a way which is simply understandable by regular investor as well as portfolio executives. The study assesses the profitability of seventy mutual funds in Malaysia by deploying riskadjusted profits from 2000 to 2011 . The ODRM is mainly measured by seventy linear encoding frameworks; as a result 7 innovative optimized risk-familiar profitability measures were planned to assess these funds. Measures assist fund executives to assess the profitability of mutual funds optimally. After that, Un-Islamic funds have the higher profitability as compares to the Islamic funds on the basis of findings of optimized measures as well as sturdiness analysis and the best part of reviewing funds do better than the standard indexes.

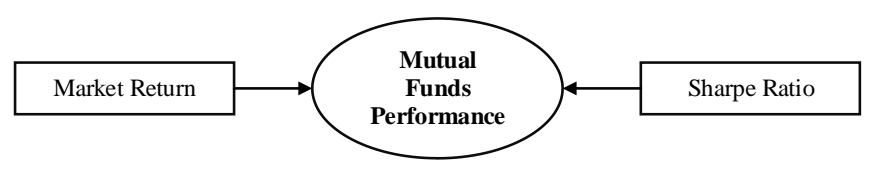

Fig.1. Conceptual framework

H1: Mutual Funds do perform better against equity market performance in Pakistan

\section{Research method}

The research method explains the facts regarding research approach, research design, sampling design which comprises of target respondents, sample size, sampling technique, instrument of data collection, and procedure of data collection and statistical technique applied for the understanding of the study. 
The explanatory research has been deployed in this project as it is suitable approach used when much is known about the research and trying to discover more about the issue and find additional explanation. Causal research design has been deployed in the study to examine the association among independent variable as well as dependent variable. This causal research aims to recognize cause-andeffect associations to demonstrate that how change in one independent variable can cause the change in dependent variable. The causal research is deployed to recognize the extent to which one variable in the research is causally related to another. The target population is mutual funds of Pakistan both close ended and open ended mutual funds.

There are total 233 mutual funds operating in the mutual industry of Pakistan, out of 233 mutual funds, total 45 mutual funds were selected for the study; 23 mutual funds were from equity while only 22 mutual funds were selected form money market.Convenience sampling technique was used in the study.

The data was collected from the website of Pakistan mutual fund association.

The data of mutual funds from Equity and Money market was collected.

The sharper ratio was used to measure the performance of Mutual Funds.

Only 3 years data was collected from 2015-2017.

The data was compiled in excel sheet and formulas was computed in excel file.

The SPSS software was used to analyze the data.

Descriptive statistics was applied to analyze the data of mutual funds association.

\section{Results and findings}

Table 4.1: Money market (Sharpe ratio)

\begin{tabular}{|c|c|c|c|c|}
\hline \multirow[t]{2}{*}{ Money Market Fund } & \multirow[t]{2}{*}{$\begin{array}{l}\text { Standard } \\
\text { Deviation }\end{array}$} & \multirow[t]{2}{*}{ Beta } & \multirow{2}{*}{$\begin{array}{l}\text { Sharpe } \\
\text { Ratio } \\
(2015- \\
2017) \\
\end{array}$} & \multirow{2}{*}{$\begin{array}{l}\begin{array}{l}\text { Average } \\
\text { Return }\end{array} \\
(2015- \\
2017) \\
\end{array}$} \\
\hline & & & & \\
\hline $\begin{array}{l}\text { Atlas Money Market } \\
\text { Fund }\end{array}$ & 0.01 & 0.15 & 0.15 & $22.20 \%$ \\
\hline $\begin{array}{l}\text { Atlas Sovereign } \\
\text { Liquid Fund }\end{array}$ & 0.40 & 0.40 & 0.15 & $25.34 \%$ \\
\hline ABL Cash Fund & 0.03 & 0.35 & 0.14 & $25.71 \%$ \\
\hline $\begin{array}{l}\text { Alfalah GHP Cash } \\
\text { Fund }\end{array}$ & 0.02 & 0.31 & 0.14 & $22.04 \%$ \\
\hline $\begin{array}{l}\text { Alfalah GHP Money } \\
\text { Market Fund }\end{array}$ & 0.01 & 0.14 & 0.13 & $21.03 \%$ \\
\hline $\begin{array}{l}\text { Askari Sovereign } \\
\text { Cash Fund }\end{array}$ & 0.04 & 0.45 & 0.14 & $24.65 \%$ \\
\hline AKD Cash Fund & 0.02 & 0.29 & 0.13 & $21.76 \%$ \\
\hline $\begin{array}{l}\text { BMA Empress Cash } \\
\text { Fund }\end{array}$ & 0.02 & 0.41 & 0.13 & $18.30 \%$ \\
\hline $\begin{array}{l}\text { Faysal Money Market } \\
\text { Fund }\end{array}$ & 0.02 & 0.26 & 0.12 & $23.01 \%$ \\
\hline $\begin{array}{l}\text { First Habib Cash } \\
\text { Fund }\end{array}$ & 0.01 & 0.22 & 0.12 & $21.57 \%$ \\
\hline $\begin{array}{l}\text { HBL Money Market } \\
\text { Fund }\end{array}$ & 0.02 & 0.23 & 0.12 & $21.72 \%$ \\
\hline HBL Cash Fund & 0.02 & 0.26 & 0.12 & $25.38 \%$ \\
\hline JS Cash Fund & 0.01 & 0.12 & 0.12 & $22.12 \%$ \\
\hline $\begin{array}{l}\text { Lakson Money } \\
\text { Market Fund }\end{array}$ & 0.01 & 0.19 & 0.13 & $22.40 \%$ \\
\hline $\begin{array}{l}\text { MCB Cash } \\
\text { Management } \\
\text { Optimizer }\end{array}$ & 0.02 & 0.25 & 0.13 & $23.22 \%$ \\
\hline $\begin{array}{l}\text { Pakistan Cash } \\
\text { Management Fund }\end{array}$ & 0.03 & 0.33 & 0.13 & $24.87 \%$ \\
\hline $\begin{array}{l}\text { NAFA Government } \\
\text { Securities Liquid } \\
\text { Fund }\end{array}$ & 0.03 & 0.37 & 0.12 & $23.28 \%$ \\
\hline $\begin{array}{l}\text { NAFA Money Market } \\
\text { Fund }\end{array}$ & 0.01 & 0.11 & 0.11 & $23.42 \%$ \\
\hline NIT Government & 0.00 & 0.06 & 0.12 & $0.00 \%$ \\
\hline
\end{tabular}

\begin{tabular}{lllll}
\hline Treasury Fund & & & & \\
PIML Daily Reserve & 0.01 & 0.24 & 0.15 & $23.31 \%$ \\
$\begin{array}{l}\text { Fund } \\
\text { UBL Liquidity Plus }\end{array}$ & 0.01 & 0.20 & 0.16 & $21.66 \%$ \\
$\begin{array}{l}\text { Fund } \\
\text { UBL Money Market }\end{array}$ & 0.02 & 0.40 & 0.21 & $19.67 \%$ \\
\begin{tabular}{l} 
Fund \\
\hline
\end{tabular}
\end{tabular}

Table 4.1 summarizes the standard deviation, beta, average return and Sharpe ratio of mutual funds of money market. The Sharpe ratio was implied to indicate the risk adjusted performance. Each funds having positive Sharpe ratio which indicates their better performance from last three years and they have favorable risk adjusted performance. It also indicates that their management have invested in the funds and have diversify portfolios and they are getting good retunes overall.

\begin{tabular}{|c|c|c|c|c|}
\hline Equity & $\begin{array}{l}\text { Standard } \\
\text { Deviation }\end{array}$ & Beta & $\begin{array}{l}\text { Sharpe } \\
\text { Ratio } \\
\text { (2015- } \\
\text { 2017) } \\
\end{array}$ & $\begin{array}{l}\text { Average } \\
\text { Return } \\
(2015- \\
2017) \\
\end{array}$ \\
\hline $\begin{array}{l}\text { Atlas Stock Market } \\
\text { Fund }\end{array}$ & 0.17 & 0.51 & 0.51 & $68.19 \%$ \\
\hline ABL Stock Fund & 0.19 & 0.57 & 0.51 & $86.10 \%$ \\
\hline $\begin{array}{l}\text { Alfalah GHP Alpha } \\
\text { Fund }\end{array}$ & 0.18 & 0.61 & 0.52 & $87.52 \%$ \\
\hline $\begin{array}{l}\text { Alfalah GHP Stock } \\
\text { Fund }\end{array}$ & 0.18 & 0.62 & 0.53 & $88.80 \%$ \\
\hline Askari Equity Fund & 0.16 & 1.10 & 0.53 & $27.91 \%$ \\
\hline AKD Opportunity Fund & 0.2 & 0.55 & 0.53 & $106.32 \%$ \\
\hline $\begin{array}{l}\text { Golden Arrow } \\
\text { Selected Stock Fund }\end{array}$ & 0.2 & 0.39 & 0.54 & $129.58 \%$ \\
\hline $\begin{array}{l}\text { First Capital Mutual } \\
\text { Fund }\end{array}$ & 0.19 & 1.10 & 0.55 & $45.29 \%$ \\
\hline First Habib Stock Fund & 0.18 & 0.84 & 0.55 & $40.97 \%$ \\
\hline HBL Stock Fund & 0.18 & 0.75 & 0.55 & $37.44 \%$ \\
\hline HBL Energy Fund & 0.19 & 0.62 & 0.56 & $36.75 \%$ \\
\hline PICIC Growth Fund & 0.18 & 0.64 & 0.57 & $28.68 \%$ \\
\hline $\begin{array}{l}\text { PICIC Investment } \\
\text { Fund }\end{array}$ & 1.02 & 4.01 & 0.58 & $26.81 \%$ \\
\hline HBL Equity Fund & 0.2 & 0.85 & 0.39 & $51.42 \%$ \\
\hline JS Growth Fund & 0.17 & 0.46 & 0.37 & $60.68 \%$ \\
\hline JS Large Capital Fund & 0.19 & 0.43 & 0.38 & $99.21 \%$ \\
\hline JS Value Fund & 0.17 & 0.67 & 0.39 & $56.66 \%$ \\
\hline Lakson Equity Fund & 0.17 & 0.65 & 0.39 & $73.26 \%$ \\
\hline $\begin{array}{l}\text { MCB Pakistan Stock } \\
\text { Market Fund }\end{array}$ & 0.18 & 0.60 & 0.38 & $89.98 \%$ \\
\hline NAFA Stock Fund & 0.17 & 0.50 & 0.38 & $104.07 \%$ \\
\hline $\begin{array}{l}\text { National Investment } \\
\text { Unit Trust }\end{array}$ & 0.16 & 0.44 & 0.39 & $78.52 \%$ \\
\hline $\begin{array}{l}\text { PIML Value Equity } \\
\text { Fund }\end{array}$ & 0.18 & 0.81 & 0.44 & $40.17 \%$ \\
\hline $\begin{array}{l}\text { UBL Stock Advantage } \\
\text { Fund }\end{array}$ & 0.18 & 0.59 & 0.39 & $81.09 \%$ \\
\hline
\end{tabular}

Table 4.2 highlights the details of beta, standard deviation, average return from 2015 to 2017 and Sharpe ratio. The Sharpe ratio discovers that how much investor have paid against the risk an investor have taken and effectiveness of funds executives that how much income funds manager can generated and the ratio also reveals about the diversification of the portfolios. The study computed the Sharpe ratio of mutual funds of equity on yearly basis of 23 mutual funds from 2015 to 2017. The finding in table 4.2 indicates that there is not a single fund with negative returns and this phenomenon is evident of the performance and effectiveness on funds and capacity to diversify in winning way.

Note: The overall Sharpe ratio is 78.76 and the ratio of market return is 20.22 , it means that Sharpe ratio is greater than market ratio.

Table 4.3: Descriptive statistics

\begin{tabular}{|c|c|c|c|c|}
\hline & $\mathbf{N}$ & Minimum Maxi & Mean & Std. Dev \\
\hline Average Return & 45 & 1.30 & .4493 & .31131 \\
\hline Sharpe Ratio & 45 & .22 & .5633 & .16143 \\
\hline
\end{tabular}


The results of descriptive statistics are shown in Table 4.3 it's clear from the findings that Average return is .4493 percent with a standard deviation of .31131 , in comparison Sharpe Ratio earned a rate .5633 percent with a standard deviation of .16143 during last three years period i-e 2015 to 2017 . Whether the rate of return on mutual funds is greater than the average market returns?

The Sharpe ratio is 78.76 and the ratio of market return is 20.22 , it means that Sharpe ratio is greater than average market return.

Whether the fund managers have the ability to diversify investment in mutual funds to eliminate systematic risk? The Sharpe ratio in both equity funds and money market funds are positive, thus indicating that funds managers have the ability to diversify investment to decrease the risk.

Table 4.4: Hypotheses assessment summary table

\begin{tabular}{lllll}
\hline Hypothesis & $\begin{array}{l}\text { Mean } \\
\text { Value }\end{array}$ & $\begin{array}{l}\text { Sharpe } \\
\text { Ratio }\end{array}$ & $\begin{array}{l}\text { Market } \\
\text { Ratio }\end{array}$ & $\begin{array}{l}\text { Empirical } \\
\text { Conclusion }\end{array}$ \\
\hline $\begin{array}{l}\text { H1: Mutual Funds do } \\
\text { perform better against }\end{array}$ & .5633 & 78.76 & 20.22 & Accepted \\
equity market \\
performance in
\end{tabular}

\section{Conclusion and discussion}

Mutual funds play a vital part for channelizing as well as most favorable distribution of inoperative capital/investments obtainable in the wealth of the person and institutional shareholder. The mutual funds are asset managing organizations that spend in stock, bond as well as additional kinds of capital market or mixture of the security. The main ambition of mutual fund is group little investment, employ the inactive income in companies as well as invests in a healthy expand portfolio of security, that can help the investor to considerably decrease, or constant eradicate the non market security risk. The existence of mutual funds turn out to be even further necessary whenever the shareholder/saver do not have greatly savings information, data as well as investment environment and services and have less risk acceptance intensity which is a extremely leading feature of Pakistani assets market (Afza \& Rauf, 2009). Augmented amount of mutual fund above the globe, mostly in industrial nations, is a sign of investors' first choice for meandering form of less-risky savings. Throughout the precedent some years, the mutual fund manufacturing has practiced a marvelous development, while, mutual fund is still a new event in up-and-coming markets. This marvelous development has guide toward the formation of different kinds of mutual funds. These kinds is classify in 2 wide segments: open-ended as well as close ended. The unrestricted funds are resources salvation of these and payment of share that is too known as component is allowable on repeated base. The funds are too described as comprise no consumers however the shareholders simply. The close ended funds, conversely, every called up as well as promised simply one time at the beginning of the fund as well as after that listed in the secondary money markets among the broad public. The results indicate that the overall Sharpe ratio is 78.76 and the ratio of market return is 20.22, it means that Sharpe ratio is greater than market ratio. Mutual fund is a savings vehicle which helps saver to pool their amounts as well as invest it in a portfolio of assets. The portfolio consists of several classes including Company's Equity Shares, Preferred Shares, Investment Bonds, Pension Fund, Islamic Fund, Real Estate Properties, Specialty Fund and Commodities. The growth in the industry of mutual fund is massive in recent years. It's not unfortunate that mutual fund has now become the best investment product among Pakistan's households. Due to the fact that Pakistan is an Islamic country and mutual fund sometime measured as Haram so Muslims think twice before invest in mutual fund. There are number of other factors which makes difficult for people to consider their investment in the mutual fund. Therefore, the factors that individual investors consider important are needed to be studied. Therefore, this thesis identifies that which criteria are considered important by the Individual investors. Most importantly, the factors which are included in the study are demographic profile, monthly income, past performance of mutual fund, religious background and category of fund. To observe which criterion is measured significant in choosing a mutual fund is important. Similarly, Belgacem and Hellara (2011) conducted a research in Tunisia and identified that precedent performance of Fund is most important criteria. Apart from past performance, there are several other variables that might have an impact on selection criteria. Abdullah, Hassan, and Mohamad (2007) describes that Islamic funds are based on the Islamic principles which prohibit dealing in interest based securities. Jamaludin, Smith, and Gerrans (2012) identified that mostly Muslim investors perceived that funds based on Islamic principles should be prioritized in selecting a fund. These Islamic funds help Muslim shareholder to be conventional toward the religious faith in investing.

Mutual fund industry in Pakistan is still in growing phase, the success of this sector depends on the performance of funds industry and the role of regulatory bodies. Excellent performance and stringent regulations will increase the popularity of mutual funds in Pakistan.

\section{Recommendations}

The recommendations are to compare the performance of mutual funds based on the religion, demographic factors and based on type of mutual funds. There are different kinds of mutual funds so therefore future research can add more performance measures tools in the study to investigate further.

\section{References}

Abdullah, F., Hassan, T., \& Mohamad, S. (2007). Investigation of performance of Malaysian Islamic unit trust funds: Comparison with conventional unit trust funds. Managerial Finance, 33(2), 142-153.

Afza, T., \& Rauf, A. (2009). Performance evaluation of Pakistani mutual funds. Pakistan economic and social review, 199-214.

Baghdadabad, M. R. T., Nor, F. M., \& Ibrahim, I. (2011). An Empirical Analysis of Funds 'alternative Measures in the Drawdown Risk Measure (DRM) Framework. Journal of Advanced Studies in Finance, 2(2 (4)), 16.

Baghdadabad, M., Matnor, F., \& Ibrahim, I. (2012). Optimized drawdown risk in evaluating the performance of Malaysian mutual funds. Journal of Islamic Accounting and Business Research, 3(2), 138-162.

Badrinath, S. G., \& Gubellini, S. (2012). Does conditional mutual fund outperformance exist?. Managerial Finance, 38(12), 1160-1183.

Banko, J., Beyer, S., \& Dowen, R. (2010). Economies of scope and scale in the mutual-fund industry. Managerial finance, 36(4), 322-336.

Beaumont, R., van Daele, M., Frijns, B., Lehnert, T., \& Muller, A. (2008). Investor sentiment, mutual fund flows and its impact on returns and volatility. Managerial Finance, 34(11), 772-785.

Belgacem, S., \& Hellara, S. (2011). Predicting Tunisian mutual fund performance using dynamic panel data model. The Journal of Risk Finance, 12(3), 208-225.

Noulas, A., A. Papanastasiou, J., \& Lazaridis, J. (2005). Performance of mutual funds. Managerial finance, 31(2), 101-112.

Jamaludin, N., Smith, M., \& Gerrans, P. (2012). Mutual fund selection criteria: evidence from Malaysia. Asian Review of Accounting, 20(2), 140-151.

Kaleem, A., \& Ahmed, S. (2009). The Quran and poverty alleviation: A theoretical model for charity-based Islamic microfinance institutions. Nonprofit and Voluntary Sector Quarterly.

Khorana, A., Servaes, H., \& Tufano, P. (2005). Explaining the size of the mutual fund industry around the world. Journal of Financial Economics, 78(1), 145-185.

Lee, T., Yun, T., \& Haley, E. (2013). Effects of mutual fund advertising disclosures on investor information processing and decision-making. Journal of Services Marketing, 27(2), 104-117.

Nazir, M. S., \& Nawaz, M. M. (2010). The determinants of mutual fund growth in Pakistan. International Research Journal of Finance and Economics, 54(10).

Reza, M., \& Glabadanidis, P. (2013). Evaluation of Malaysian mutual funds in the maximum drawdown risk measure framework. International Journal of Managerial Finance, 9(3), 247-270. 
Soongswang, A., \& Sanohdontree, Y. (2011). Open-ended equity mutual funds. International Journal of Business and Social Science, 2(17).
Soongswang, A., \& Sanohdontree, Y. (2011). Equity mutual fund: performances, persistence and fund rankings. Journal of Knowledge Management, Economics and Information Technology, 1(6), 425-452. 